\title{
Analisis Sektor Usaha Kecil \& Menengah Menjadi Model Kewirausahaan Sosial Berbasis Ekonomi Kreatif
}

\author{
Dedi Rianto Rahadi \\ Department Management, Faculty of Business, President University \\ J1. Ki Hajar Dewantara, Kota Jababeka, Cikarang Baru, Bekasi 17550, Indonesia \\ Email : dedi1968@president.ac.id
}

\begin{abstract}
Kewirausahaan Sosial merupakan suatu konsep kewirausahaan (entrepreneurship) yang mengedepankan aktivitas sosial dengan memberdayakan masyarakat sekitar. Usaha Kecil \& Menengah (UKM) dapat dilibatkan menjadi bagian dari Social-entrepreneurship, untuk mendukung kemandirian masyarakat secara ekonomi. Untuk mendukung keberlangsungan UKM serta jangkauan yang lebih global dapat digunakan pendekatan ekonomi kreatif dari setiap sektor yang dilakukan UKM. Hal ini bertujuan keberlangsungan UKM dapat berlangsung lama dan menjadi pondasi bagi perekonomian Indonesia. Tujuan penelitian untuk melakukan analisis UKM agar menjadi bagian dari social entrepreneuship berbasis ekonomi kreatif. Metode penelitian secara kuantitatif (statistik deskriptif) dan kualitatif (model analisis interaktif), dimana pengumpulan data dilakukan secara observasi, wawancara mendalam, dan pendekatan Teknik PRA (Participatory Rural Appraisal). Hasil penelitian menunjukkan pemerintah daerah mendukung sepenuhnya keberadaan UKM khususnya sektor kerajinan, dengan memberikan fasilitas berubah kebijakan maupun bantuan pendanaan. Sebagian pengrajin sudah memiliki konsep ide maupun kreatifitas dalam meningkatkan kualitas produk, hal ini terlihat dari inovasi produk yang dikembangkan. Masyarakat, pemerintah dan komunitas pengrajin mendukung keberadaan kewirausahaan sosial berbasis ekonomi kreatif guna mendukung peningkatan perekonomian. Untuk mendukung keberlangsungan kewirausahaan sosial berbasis ekonomi kreatif dibutuhkan keterlibatan pemerintah, pengusaha, masyarakat melalui pendampingan secara berkelanjutan dengan dukungan kebijakan yang berpihak kepada UKM.
\end{abstract}

Keywords: social entrepreneurship, Usaha Kecil \& Menengah (UKM), ekonomi kreatif

\begin{abstract}
Social Entrepreneurship is a concept of entrepreneurship (entrepreneurship) that prioritizes social activities by empowering the surrounding community. Small and Medium Enterprises (SMEs) can be involved to be part of Social-entrepreneurship, to support economic independence of society. To support the sustainability of SMEs as well as a more global reach can be used creative economic approach of each sector conducted SMEs. It aims to sustain SMEs for a long time and become the foundation for the Indonesian economy. The purpose of the research is to conduct SME analysis to be part of social entrepreneuship based on creative economy. Quantitative research methods (descriptive statistics) and qualitative (interactive analysis models), where data collection is done by observation, in-depth interviews, and approach of PRA (Participatory Rural Appraisal). The results show that local governments fully support the existence of SMEs, especially the handicraft sector, by providing facilities to change policies and funding assistance. Some craftsmen already have the concept of ideas and creativity in improving product quality, it is seen from the innovation of products developed. Society, government and community of artisans support the existence of creative economy-based social entrepreneurship in order to support the improvement of the economy. To support the sustainability of creative entrepreneurial based on creative economy requires the involvement of government, entrepreneurs, communities through ongoing assistance with policy support siding with SMEs.
\end{abstract}


Keywords: social entrepreneurship, Small \& Medium Enterprises (SMEs), creative economy

\section{A. Latar Belakang}

Kewirausahaan Sosial telah menjadi prioritas dalam mengedepankan aktivitas sosial dengan memberdayakan masyarakat sekitar melalui sektor ekonomi. Model ini dapat menjadi solusi bagi permasalahan sosial yang tengah dihadapi masyarakat Indonesia, khususnya kemandirian dalam bidang ekonomi. London \& Morfopoulus, 2010:7), menyatakan:

"social entrepreneur combine approaches of business and social welfare". They identify under-utilized resources - people, buildings, equipment- and find ways of putting them to use to satisfy unmet social needs. They bridge gaps between social needs and current services.

Dari pendapat tersebut dapat disimpulkan, bahwa kegiatan kewirausahaan sosial dapat dilaksanakan dengan menggabungkan pendekatan bisnis dan sosial. Sinergi antara pemilik modal, pengelola dan masyarakat dapat memberikan nilai tambah serta nilai sosial bagi peningkatan kemandirian dibidang ekonomi. Karen Braun (2009) menyatakan, kewirausahawan sosial adalah seseorang yang dapat mengenali masalah sosial serta menjalankan strategi kewirausahaan guna menghadapi setiap risiko yang akan terjadi melalui perubahan-perubahan positif. Kewirausahaan Sosial akan memiliki nilai tambah bila didukung melalui ekonomi kreatif dan industri kreatif yang merupakan satu kesatuan dan memiliki keterkaitan satu sama lainnya.

Kota Tasikmalaya merupakan salah satu sentra industri yang banyak menghasilkan berbagai macam sektor usaha, diantaranya kerajinan tangan, kuliner dan fashion. Sektor ini dapat menjadi pintu masuk industri kreatif dalam bentuk kewirausahaan sosial. Industri kreatif di Indonesia telah memberikan kontribusi untuk membantu perekonomian nasional sebesar 11\%, lihat gambar 1 (sumber BPS, Pusdatin Kemenperin, 2016).

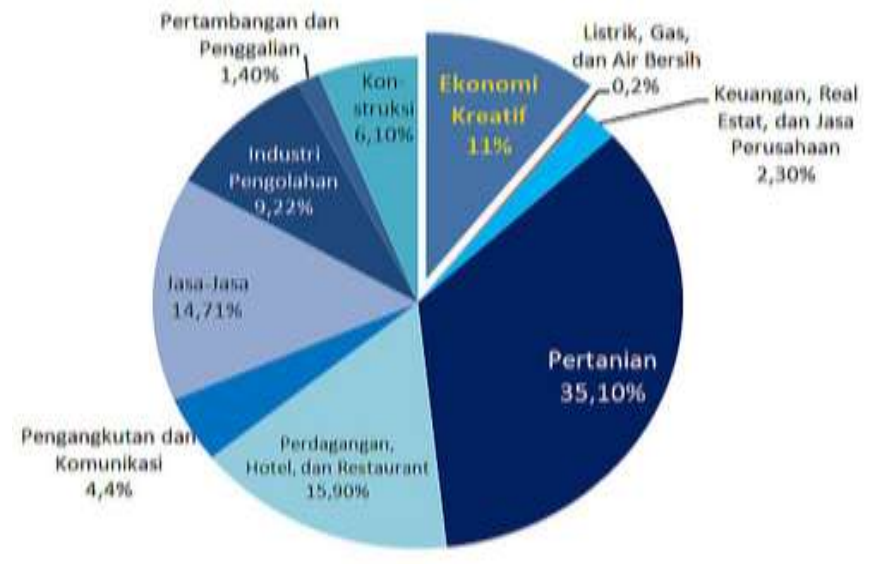

\section{Gambar 1 Persentase Kontribusi Berbagai Sektor Di Indonesia}

Data tersebut mencerminkan ekonomi kreatif telah memberikan kontribusi yang cukup signifikan bagi pendapatan negara. Dengan semakin tingginya pertumbuhan ekonomi digital kedepannya diharapkan dapat menjadi alasan bagi setiap pemerintah daerah khususnya Kota 
Tasikmalaya dalam mengembangkan sektor UKM untuk mendukung kewirausahaan sosial berbasis ekonomi kreatif.

Identifikasi masalah tercermin dari masalah mendasar di bidang ekonomi yang dihadapi kota Tasikmalaya adalah daya beli masyarakat yang tergolong rendah hanya Rp. 631.750,- per kapita (2011), tingkat kemiskinan yang tinggi (19,98\%) dan pengangguran yang besar $(9,14 \%)$.

(sumber

http://www.bsn.go.id/uploads/download/Kesiapan_Tasikmalaya_menghadapi_MEA_BudiBu diman1.pdf). Kondisi harus segera dicarikan solusinya guna menumbuhkan tingkat kepercayaan masyarakat terhadap pemerintah maupun memanfaatkan potensi yang dimiliki masyarakat. Dari hasil pra survey yang dilakukan permasalahan secara umum yang dihadapi UKM 1) masih lemahnya design dan kualitas produk, 2). minimya pemanfaatan teknologi informasi (TI) dalam mengelola usaha, 3). segmen pasar global belum digarap secara optimal, melalui pemanfaatan sosial media, 4). keterbatasan dalam permodalan, informasi pasar, marketing, sarana dan prasarana produksi

Jumlah UKM di kota Tasikmalaya (Tabel 1) setelah diolah menunjukkan pengrajin payung geulis dan batik relatif masih sangat sedikit hanya jumlahnya dibawah 50 pengrajin bila dibandingkan dengan kerajinan lainnya. Hal ini menunjukkan pengembangan usaha payung geulis dan batik relatif lambat. Kondisi ini perlu menjadi perhatian pemerintah agar kerajinan tersebut tidak hilang dari kota Tasikmalaya.

\section{Tabel.1 Komoditi dan Jumlah UKM}

\begin{tabular}{|c|c|c|}
\hline NO & KOMODITI DAN KLASIFIKASI INDUSTRI & UNIT USAHA \\
\hline \multicolumn{3}{|c|}{ E. KOMODITI UNGGULAN : } \\
\hline 1 & Bordir & 1,356 \\
\hline 2 & Kerajinan Mendong & 173 \\
\hline 3 & Kerajinan Bambu & 75 \\
\hline 4 & Alas Kaki (Kelom Geulis, Sandal, Sepatu) & 509 \\
\hline 5 & Kayu Olahan (Meubol) : & 202 \\
\hline 6 & Batik & 41 \\
\hline 7 & Payung Geulis & 7 \\
\hline \multirow[t]{2}{*}{8} & Makanan Olahan & 525 \\
\hline & JUMLAH A .......................... & $2,8 \mathrm{Ba}$ \\
\hline \multicolumn{3}{|c|}{ 1. KOMODITI LAINNYA } \\
\hline 1 & Bahan Bangunan & 302 \\
\hline 2 & Pakaian Jadi & 84 \\
\hline 3 & Percetakan & 34 \\
\hline \multirow[t]{3}{*}{4} & Lain-lain & 110 \\
\hline & JUMLAH B ................ & 530 \\
\hline & TOTAL A+B .......................... & 3,418 \\
\hline
\end{tabular}

Sumber : https://tasikmalayakota.bps.go.id/

Dari permasalahan tersebut dapat menjadi peluang dan tantangan bagi pemerintah daerah maupun pengrajin yang ada untuk menjaga keberlangsungan UKM dan diharapkan dapat menjadi bagian dari kewirausahaan social. Keberadaan infrastruktur teknologi informasi (TI) yang semakin mudah diperoleh dan murah akan semakin mempermudah terwujudnya UKM 
berbasis ekonomi kreatif. Kolaborasi UKM dengan masyarakat sekitarnya akan semakin memperkuat terwujudnya social entrepreneurship.

Kewirausahaan sosial tidak hanya menghasilkan laba tetapi juga dapat meningkatkan taraf hidup masyarakat dengan mengurangi kesenjangan sosial. Munculnya ide dan dan adanya keinginan untuk meningkatkan taraf hidup masyarakat melalui usaha bersama-sama untuk menghasilkan keuntungan. Sebahagian keuntungan yang diperoleh akan digunakan untuk membangun usaha yang baru yang akan dikelola masyarakat dan seterusnya. Adapun perumusan masalah adalah bagaimana usaha kecil dan menengah dapat menjadi bagian social entrepreneuship berbasis ekonomi kreatif ? Tujuan penelitian sebagai berikut a). untuk melakukan analisis UKM menjadi bagian dari social entrepreneuship berbasis ekonomi kreatif. b). untuk membuat model social entrepreneuship berbasis ekonomi kreatif.

\section{B. Landasan Teori}

\section{a. Kewirausahaan Sosial}

Banyak riset tentang kewirausahaan sosial, seperti yang dilakukan oleh Haryadi dan Waluyo (2006), Rahmawati et al., (2011), Palesangi (2012), Situmorang dan Marzanti (2012), Pratiwi dan Siswoyo (2014), serta Utomo (2014), mengemukakan wirausaha sosial di Indonesia, dapat berkembang dengan cepat, dimana ada keyakinan bahwa kewirausahaan sosial dapat membantu mengatasi permasalahan sosial.

Kewirausahaan sosial memiliki peran yang penting dalam memberikan solusi guna mengurangi kemiskinan. Implementasi social business akan semakin menguatkan bahwa keberadaan kewirausahaan akan menjadi pendorong pekonomian bagi masyarakat guna memperbaiki perekonomian dan meningkatan pendapatan serta taraf hidup masyarakat (Firdaus, N, 2014). Hulgard (2010) juga mengungkapkan social entrepreneurship sebagai penciptaan nilai sosial yang dibentuk dengan cara bersinergi dengan orang lain atau komunitas masyarakat yang terlibat dalam suatu inovasi sosial dalam kegiatan ekonomi. Yunus, 2007; Jiao, 2011, mengemukakan beberapa alasan mengapa munculnya kewirausahaan sosial, pertama, belum optimalnya pemerintah dalam menyelesaikan masalah sosial karena implementasi kebijakan yang dibuat tidak efektif.

Kedua, kurang mandirinya organisasi nirlaba secara finansial untuk membiayai aktivitas sosial, dan sangat tergantung pihak donor dalam mendukung aktivitas sosialnya. Ketiga organisasi multilateral, seperti dunia perbankan yang seharusnya dapat mendorong pertumbuhan ekonomi, tetapi kenyataannya belum mengarah pada penurunan kemiskinan (pro poor growth versus anti-poor growth). Keempat, kegiatan Corporate Social Responsibility (CSR) yaitu tanggung jawab perusahaan terhadap masyarakat dan lingkungan sekitar perusahaan berdiri belum optimal dalam memberikan manfaat sosial dan kemandiran masyarakat.

\section{b. Konsep kewirausahaan sosial}

Masyarakat dilibatkan untuk berpartisipasi dalam kewirausahaan sosial untuk melakukan perubahan, memberikan ide kreatif dan inovatif dengan memanfaatkan sumberdaya yang dimiliki. Noruzi et al., 2010; Patra dan Nath, 2014, mengemukakan bahwa konsep kewirausahaan sosial adalah perluasan dari konsep dasar kewirausahaan yang secara historis telah diakui sebagai pendukung kegiatan ekonomi, terutama dalam menyelesaikan masalah 
sosial. Kewirausahaan sosial dapat merubah perilaku individu dalam melaksanakan kegiatan usahanya melalui pemanfaatan berbagai peluang untuk dapat menciptakan nilai tambah. Dalam konteks kewirausahaan sosial, nilai yang dicapai adalah nilai sosial dimana penekanan pada ide-ide kreatif dan inovatif dalam menyelesaikan permasalahan sosial.

Nicholls (2006), menyatakan membagi dua faktor pendorong tumbuhnya kewirausahaan sosial yaitu sisi penawaran dan sisi permintaan. Dari sisi penawaran, kesejahteraan masyarakat global dan bertambahnya masa usia produktif akan mendorong mobilitas sosial, sehingga mengarah kepada kesadaran kolektif untuk memperbaiki kualitas hidup. Kekuatan perusahaan multinasional memainkan peranan penting dalam dinamika ekonomi global dan dampaknya terhadap pertumbuhan ekonomi lokal serta konsep model bisnis. Dari sisi permintaan, kehadiran kewirausahaan sosial memberikan jawaban atas ketimpangan ekonomi. Pemerintah memberikan berbagai pelayanan publik kepada masyarakat, justru terkendala pada masalah inefisiensi.

Perrini dan Vurro (2006) manambahkan bahwa kewirausahaan sosial secara aktif memberikan kontribusi bagi perubahan sosial dengan kreativitas dan inovasi dengan berlandaskan pada praktik kewirausahaan. Kewirausahaan sosial diharapkan dapat menjadi penggerak perubahan, berinovasi dalam bidang sosial yang menuju pada kemandirian masyarakat.

\section{c. Model Bisnis Social Entrepreneurship}

Osterwalder \& Pigneur (2010) mengemukan model bisnis sebagai gambaran dasar pemikiran tentang bagaimana organisasi menciptakan dan memberikan nilai tambah bagi masyarakat. Model bisnis menunjukkan bagaimana cara berpikir sebuah perusahaan menghasilkan uang. Model bisnis dan bentuk organisasi sangat berpengaruh terhadap kemampuan perusahaan untuk tumbuh dan berkembang secara berkelanjutan. Seperti halnya bisnis pada umumnya, kesempatan yang dimiliki social entrepreneurship harus didukung oleh model bisnis yang rasional dan realistis. Kehadiran social entrepreneur dapat menciptakan model bisnis baru dimana model tersebut diharapkan dapat meningkatkan kinerja para pengusaha sosial. Beberapa literatur mengenai model bisnis social entrepreneurship menyarankan desain model bisnis untuk social entrepreneurship seperti yang digambarkan dalam gambar 2. dibawah ini. Desain model bisnis sosial sebagai pendekatan sistematis dan komprehensif yang mengatur bisnis sosial di tiga bidang utama: optimalisasi rekan bisnis, kolaborasi sumber daya manusia dan adanya partisipasi pelanggan. Ketiga bidang tersebut memiliki peluang yang sama untuk peningkatan hasil mulai dari efisiensi biaya hingga inovasi produk dan pelayanan baru serta dapat meningkatkan arus pendapatan. 


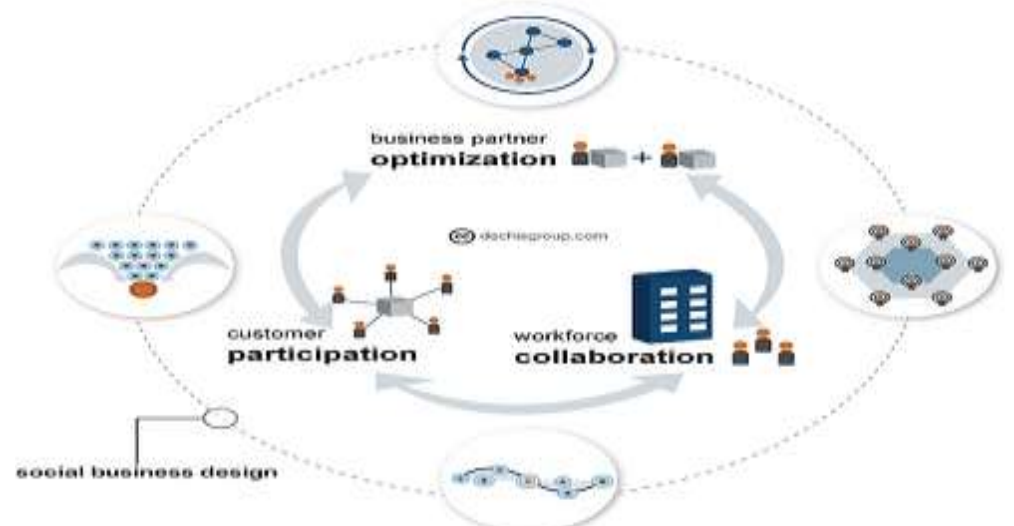

\section{Gambar 2. Desain Model Bisnis Social Entrepreneurship}

Sumber : http://darmano.typepad.com

Hal ini dapat terjadi apabila organisasi menghubungkan dan memperluas ekosistem, berevolusi menuju budaya yang transparan dengan memberdayakan karyawan, mitra bisnis dan pelanggan untuk bersinergi dalam bisnis sosial.

\section{d. Ekonomi Kreatif}

Dalam cetak biru Pengembangan Ekonomi Kreatif Indonesia 2009-2015, dijelaskan bahwa ekonomi kreatif merupakan "Era baru ekonomi setelah ekonomi pertanian, ekonomi industri, dan ekonomi informasi, dengan memberdayakan informasi serta kreativitas. Diawali dengan memunculkan berbagai ide dan pengetahuan bersumber dari sumber daya manusia sebagai faktor produksi utama dalam kegiatan ekonomi.

Pernyataan tersebut dapat disimpulkan ekonomi kreatif adalah gagasan baru dari sistem perekonomian dengan menempatkan informasi dan kreativitas manusia sebagai faktor produksi yang menjadi prioritas utama. Konsep ide merupakan barang mahal dalam ekonomi kreatif, karena ide yang kreatif akan mendorong terciptanya inovasi-inovasi dan kemudian akan menjadi solusi baru dan produk baru. Hal ini merupakan jawaban atas permasalahan rendahnya kualitas produk yang sesuai dengan kebutuhan dan keinginan pasar.

\section{Metode Penelitian}

Objek penelitian adalah UKM di Kota Tasikmalaya khususnya pada sektor kerajinan tangan seperti payung dan kelom geulies serta baju batik. Pendekatan kualitatif digunakan dalam metode penelitian yang dikemukan (Neuman, 2007; Creswell, 2009) yang bersifat deksriptif. Untuk mendukung pendekatan tersebut, peneliti menggunakan metode penelitian lapangan (field research) sehingga dapat menjawab setiap rumusan masalah. Guna memudahkan penelitian, maka diambil data dari sumber data primer seperti:

1. Observasi

2. Wawancara langsung.

Wawancara mendalam atau in-depth interview adalah metode yang digunakan untuk mengumpulkan data atau keterangan lisan dari seseorang yang disebut informan melalui suatu percakapan yang sistematis dan terorganisasi (Silalahi, 2012). Informan utama (key 
informant), yaitu pengelola UKM, pemerintah daerah, serta komunitas masyarakat yang berada disekitar UKM.

3. Teknik PRA (Participatory Rural Appraisal).

Menurut (Adimihardja, (2003) PRA adalah suatu teknik yang memungkinkan masyarakat turut serta dalam membuat tindakan nyata, pengawasan, dan evaluasi terhadap kebijakan yang berpengaruh pada kehidupannya.

\section{Hasil Penelitian}

\section{Profil Usaha Kecil Dan Menengah Di Kota Tasikmalaya}

a. Payung Geulis

Geulis berarti cantik, elok atau molek. Payung Geulis diartikan sebagai payung cantik yang memiliki estetika sesuai dengan budaya lokal. Ada dua motif payung geulis pertama, motif hias geometris yang berbentuk bangunan, dengan model yang dominan adalah garis lurus, lengkung dan patah-patah. Kedua motif hias non geometris yang didominasi gambar alam seperti tanaman, hewan dan manusia. Payung geulis rangkanya terbuat dari bambu, Setelah dirangkai dan dipasangi kain serta kertas, ujung payung dirapikan dengan menggunakan kanji (lem). Agar lebih menarik, rangka bagian dalam diberi benang warna-warni. Harga payung ini di pasaran lokal sangat murah. Untuk satu payung ukuran kecil hanya dihargai Rp. 20.000, sedangkan ukuran sedang sampai ukuran besar berkisar Rp. 30.000 hingga Rp. 50.000. Pada gambar 3 memperlihatkan proses pembuatan payung geulis.

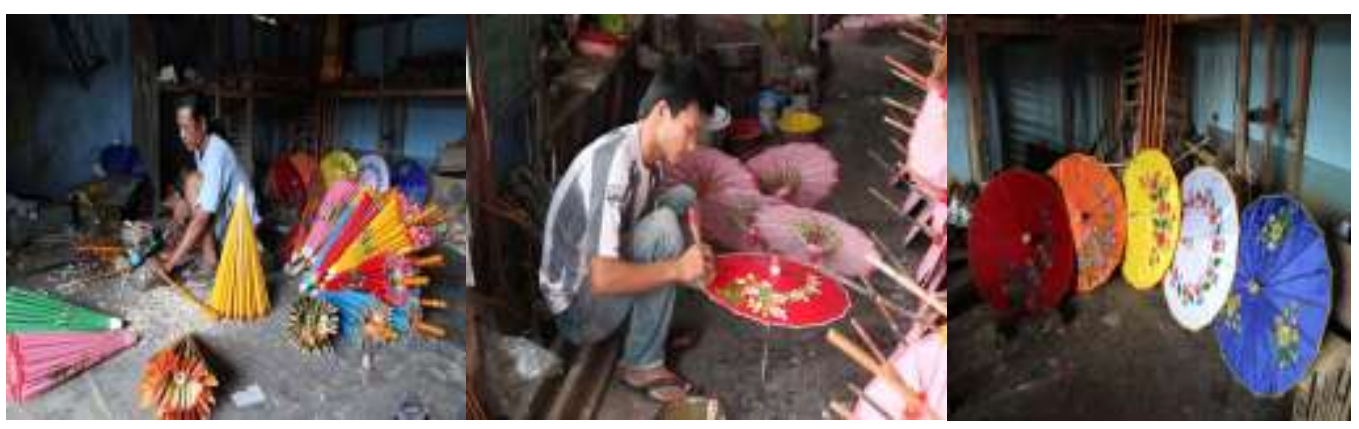

Gambar 3. Proses Pembuatan Payung Geulis

\section{b. Kelom Geulis}

Kelom Geulis diambil dari bahasa Belanda yaitu 'kelompen' yang artinya sandal kayu. Istilah Kelom Geulis Tasikmalaya sendiri berasal dari bahasa sunda yang berarti sandal kayu cantik. Kelom Geulis Tasikmalaya terbuat dari kayu mahoni atau albasia. Kelom Geulis ini di buat secara manual dengan menggunakan tangan. Agar tampak menarik, kelom di berikan hiasan. Hiasan kelom umumnya adalah hiasan ukiran dengan motif bunga. Kelom Geulis Tasikmalaya terdapat di Desa Setiamulya, Mulyasari, Kersanegara, Sukahurip, Sumelap. Pada gambar 4 memperlihatkan proses pembuatan dan produk kelom geulis yang membutuhkan ketekunan serta ketelitian tingkat tinggi untuk menghasilkan produk yang berkualitas. 


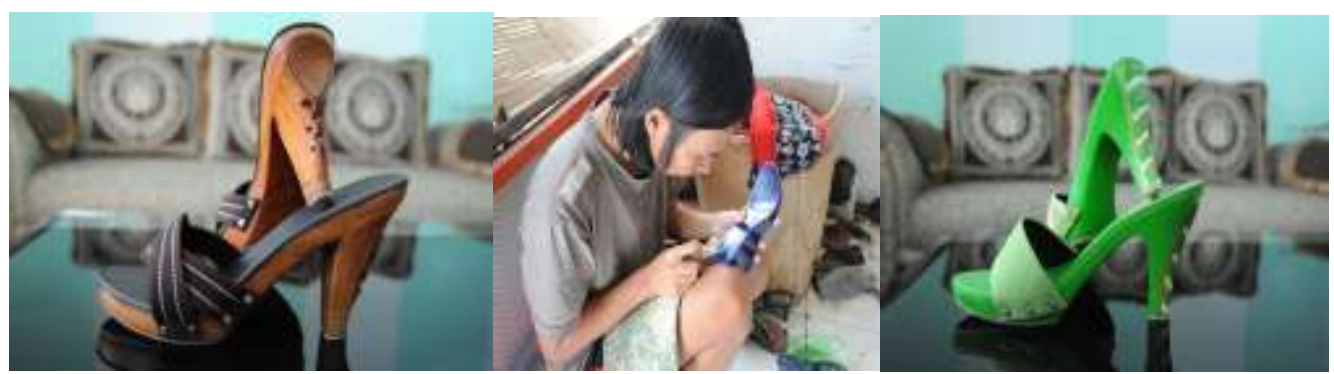

Gambar 4. Proses Pembuatan Kelom Geulis

\section{c. Batik Tasikmalaya}

Sentra batik Tasikmalaya terletak di desa sukapura kecamatan Sukaraja. Secara garis besar batik tasikmalaya memiliki motif batik yang cenderung memberikan kesan semangat kesederhanaan, terbuka, dan pluralis juga memperlihatkan kesan imut dan unyu selaras dengan citra umum wanita sunda. Motif batik Tasikmalaya mempunyai tiga motif batik populer yaitu motif batik burung, motif batik payung, dan motif batik kacang panjang yang sangat kental dengan nuansa kota Parahyangan. Pada gambar 5 memperlihatkan proses pembuatan batik.

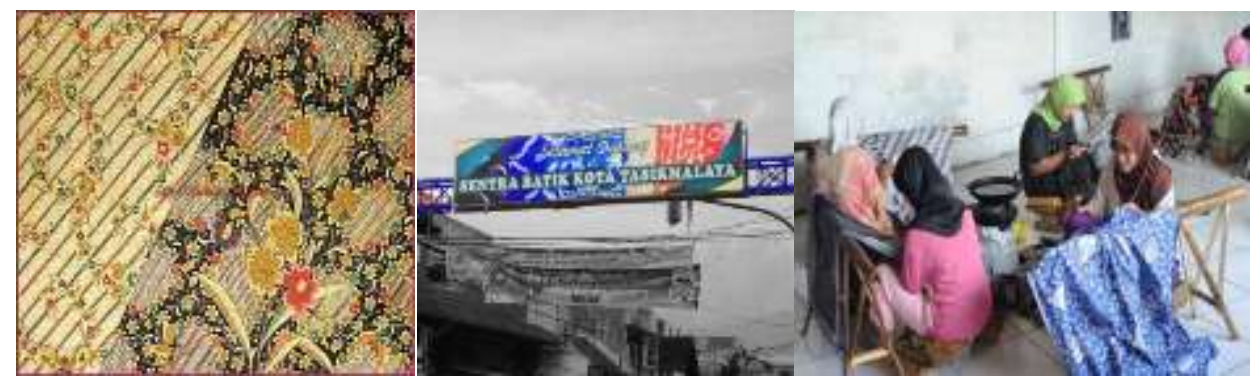

Gambar 5. Proses Pembuatan Batik Tasikmalaya

Agar branding batik Tasikmalaya tidak kalah dengan batik Yogya, Solo, Pekalongan dan lain-lainnya, dibutuhkan keterlibatan pemerintah daerah. Misalnya untuk pegawai pemerintah daerah maupun pelajar dapat menggunakan batik khas Tasikmalaya.

\section{Hasil Observasi dan Wawancara Usaha Kecil Dan Menengah Di Kota Tasikmalaya}

Terkait dengan perumusan masalah yaitu "bagaimana Mewujudkan social entrepreneuship berbasis ekonomi kreatif Sektor UKM di Kota Tasikmalaya", peneliti melakukan wawancara dengan beberapa informan sebagai berikut :

a. Hasil survey dan wawancara dengan informan Dinas Koperasi \& UMKM Perindag Kota Tasikmalaya Sebagai berikut :

Peneliti : "Upaya yang sudah dilakukan pemerintah daerah terhadap UKM".

Pemerintah Daerah : "Pemerintah sudah mengeluarkan Program Gerakan Masyarakat Mandiri, Berdaya Saing, dan Inovatif sebagai Model Pembangunan Berbasis Partisipasi Masyarakat (GEMA MADANI SIMPATI). Gerakan ini mengharapkan ada peran serta masyarakat, sifat tolong-menolong, dan gotong royong dalam kehidupan sosial. Sesuai 
dengan konsep kewirausahaan sosial dimana gerakan ini diharapkan memiliki pengaruh langsung yang dapat dirasakan oleh semua pihak. Manfaat yang ingin dicapai utamanya adalah untuk menumbuhkan kemandirian masyarakat. Disisi lain dampak dari tumbuhnya kemandirian akan munculnya semangat gotong royong, tolong-menolong, kerja sama antar anggota masyarakat, dan timbulnya kesadaran serta tanggung jawab bersama dalam membangun dan mensejahterakan masyarakat, serta rasa memiliki dan menjaga hasil-hasilnya.

Peneliti : "Permasalahan secara umum yang dihadapi UKM Kota Tasikmalaya.

Pemerintah Daerah : Secara umum permasalahan yang dihadapi sektor UKM relatif sama, diantaranya : 1) belum optimalnya design produk, sehingga terkesan tidak ada perubahan dan monoton serta minimnya kreasi baru. 2). Keterlibatan masyarakat sekitar masih minim karena merasa upah yang diberikan rendah atapun tidak memiliki ketrampilan untuk mengembangkan produk tersebut. 3) Dari sisi modal kerja relatif masih lemah, sehingga produk yang dihasilkan jumlahnya terbatas. 4) Ide kreatif dan inovatif dalam mengembangkan produk masih perlu untuk ditingkatkan. 5) Pemasaran produk masih terbatas, namun dengan adanya penjualan online sedikit banyak mampu meningkatkan penjualan.

Peneliti : Apakah bapak setuju adanya kewirausahaan sosial, seperti dompet dhuafa, rumah zakat, bank sampah dan lain-lain

Pemerintah Daerah : Woouw, kami sangat setuju sekali. Kami butuh keterlibatan semua komponen masyarakat untuk membantu pemerintah mengatasi kemiskinan melalui keterlibatan dalam sektor ekonomi. Kami siap membantu memfasilitasi terbentuknya kewirausahaan sosial melalui pendampingan dan kemudahan perizinan.

Peneliti : Bagaimana dengan ekonomi kreatif?

Pemerintah Daerah : Komitmen pemerintah untuk terus mendorong keberadaan ide, potensi dan inovasi yang dimiliki masyarakat untuk terus berkarya dan menjadi nilai jual. Ini merupakan konsep awal ekonomi kreatif.

b. Hasil survey dan wawancara dengan informan Pengrajin Kota Tasikmalaya Sebagai berikut :

Peneliti : Sudah berapa lama mengelola usahanya dan berapa banyak pengrajin disekitar wilayah bapak/ibu.

Pengrajin : Sudah cukup lama lebih dari 5 tahun dan usaha ini meneruskan usaha keluarga. Dengan banyaknya produk-produk impor dari luar dan harganya relatif murah, menyebabkan jumlah pengusaha ditempat kami relatif berkurang. Kami hanya memproduksi tidak begitu banyak dan biasanya berdasarkan pesanan. Mereka banyak beralih keusaha lain yang sifatnya tidak membutuhkan keahlian maupun tenaga kerja yang banyak. Mereka lebih senang menjual barang yang sudah jadi dibandingkan dengan membuat kerajinan atau produk dari awal.

Peneliti : Apakah bapak/ibu mengetahui tentang kewirausahaan sosial?

Pengrajin : Kami pernah mendengar kata-kata tersebut, tetapi kami belum paham dan apa manfaatnya bagi kami. 
Pengrajin : Kami menginginkan berbagi kepada sesama dengan memanfaatkan apa yang kami miliki. Kami ingin usaha yang kami miliki tidak hanya diwariskan kepada anak cucu kami, tetapi juga kepada pihak lain.

Peneliti : Apakah bapak/ibu mengetahui tentang ekonomi kreatif ?

Pengrajin : Kami mengetahui ekonomi kreatif, tetapi kami ingin pemerintah maupun lembaga lainnya dapat membantu kami untuk mewujudkan ekomi kreatif melalui pelatihan maupun pendampingan dalam menjalankan ekonomi kreatif. Kami menginginkan setiap karyawan dapat memiliki ide-ide kreatif maupun inovasi-inovasi yang dapat meningkatkan nilai jual serta kualitas.

\section{c. Hasil survey dan wawancara dengan informan konsumen/Masyarakat sekitar} sebagai berikut :

Peneliti : Bagaimana design produk dan kualitas produk produk ini ?

Konsumen : Designnya cukup baik tetapi sepertinya tidak mengalami perubahan yang berarti dengan design sebelumnya. Pewarnaannya cukup menarik namun perlu ada perpaduan antara warna dan design yang kekinian.

Peneliti : Apakah bapak/ibu menginginkan adanya keterlibatan konsumen atau masyarakat dalam meningkatkan mutu dan design produk?

Konsumen : Kami ingin terlibat dan bilamana memungkinkan kami akan ikut atau mengembangkan usaha yang sama. Dan tentunya ada keterlibatan pengrajin atau pengusaha untuk membantu memulai usaha. Pada akhirnya kami akan menjadi mandiri dan memiliki usaha sendiri yang pada akhirnya kami saling membantu satu sama lainnya. Peneliti : Apakah bapak/ibu merasakan dampak adanya usaha kerajian disekitar domisili bapak/ibu ?

Masyarakat : Ya ada sih dampaknya, tetapi untuk sementara ini kami sekedar bisa berjualan makanan/minuman. Sebagian menjadi tukang parkir untuk kendaraankendaraan pembeli.

Peneliti : Apakah bapak/ibu ada keinginan untuk menjadi pengrajin ?

Masyarakat : Wah senang sekali kami menjadi pengrajin. Kami berharap akan mendapatkan penghasilan tambahan dari usaha tersebut. Permasalahannya kami ngak punya modal dan tidak tahu harus dimulai dari mana?

Dari hasil dengar pendapat dan wawancara dengan berbagai informan (pengrajin, pemerintah, konsumen dan masyarakat) membuktikan adanya keinginan yang kuat dari semua pihak untuk menjadi mandiri dan saling membantu antar sesama. Pemerintahpun meminta bantuan kepada pengrajin untuk saling membantu dalam mengurangi kesenjangan sosial khususnya disekitar domisili pengrajin dan ikut sharing keahlian kepada masyarakat.

\section{E. Pembahasan}

\section{Model Kewirausahaan Sosial Berbasis Ekonomi Kreatif}

Di kota Tasikmalaya, dari beberapa kerajinan yang menjadi ciri khas dan menjadi fokus dalam penelitian ini adalah kelom geulies, payung geulies dan batik. 


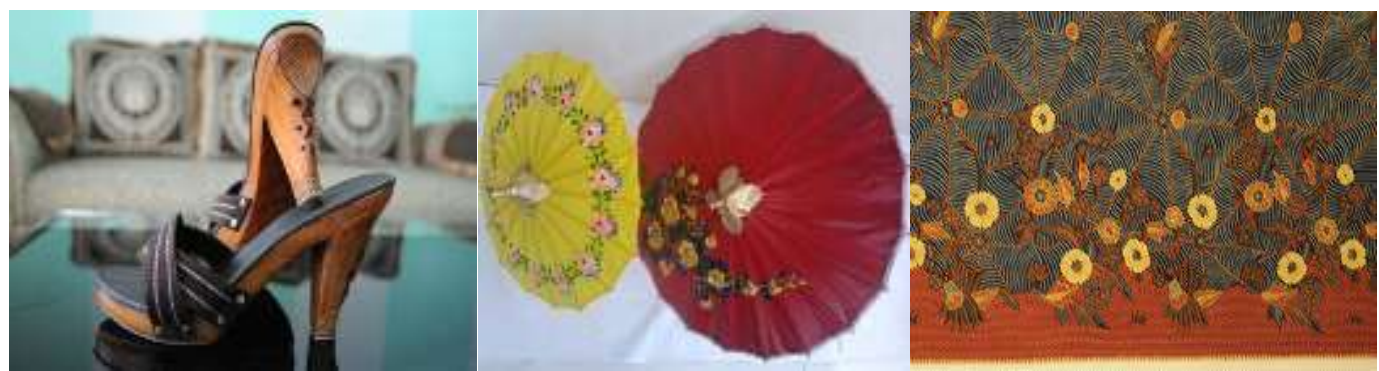

Gambar 6. Produk Kerajinan Kota Tasikmalaya

Untuk pengembangan industri kerajinan kota Tasikmalaya, diperlukan pemetaan terhadap ekosistem kerajinan yang terdiri dari rantai nilai kreatif, market, nurturance environment, marketing dan raw material. Aktor yang harus terlibat dalam ekosistem ini tidak terbatas pada model triple helix yaitu intelektual, pemerintah, dan bisnis, tetapi harus lebih luas dan melibatkan komunitas kreatif dan masyarakat konsumen karya kreatif. Dibutuhkan quad helix model kolaborasi dan jaringan yang mengaitkan intelektual, pemerintah, bisnis dan komunitas. Pada gambar 7 dijelaskan model kewirausahaan sosial berbasis ekonomi kreatif. Tujuan yang ingin dicapai dari model tersebut, komunitas pengrajin akan menjadi sosial entrepreneur dengan memberikan pelatihan dan layanan kepada konsumen serta pendampingan kepada masyarakat.

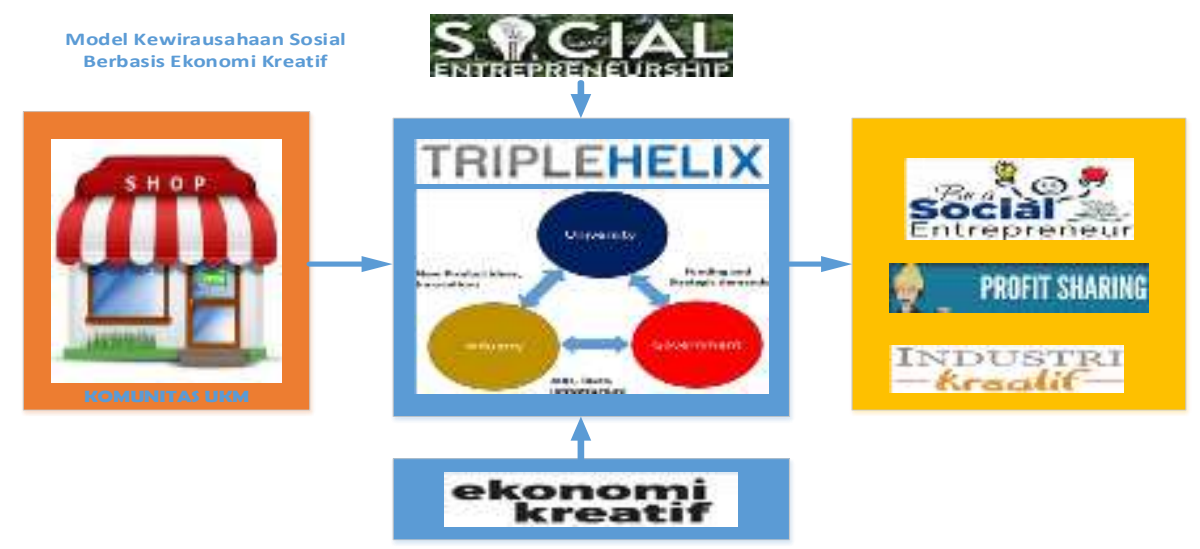

Gambar 7. Model Kewirausahaan Sosial Berbasis Ekonomi Kreatif

\section{Implementasi Kewirausahaan sosial}

Implementasi kewirausahaan sosial sesuai dengan kondisi di Kota Tasikmalaya sebagai berikut :

\section{Contoh Proses Pengembangan Ide Kewirausahaan Sosial Berbasis Ekonomi Kreatif}

\section{PANGGILAN}

a) Mengapa sektor kerajinan khas Tasikmalaya belum berkembang optimal ?

b) Mengapa keberadaan pengrajinan belum memberikan dampak sosial bagi masyarakat sekitar ? 
c) Mengapa masih minim keterlibatan masyarakat disekitar pengrajin dalam mengembangkan potensi kerajian?

d) Mengapa desain produk yang dihasilkan belum menggambarkan desain kekinian?

\section{IDE}

Saya ingin memperbaiki pengelolaan sektor kerajinan, mulai dari desain dan proses produk, pemasaran maupun manajemen di lingkungan sekitar pengrajin dahulu. Kalau pengeloaan sektor kerajinan sudah baik, saya akan melibatkan masyarakat sekitar untuk membantu dalam mengembangkan produk yang berkualitas. Pada akhirnya masyarakat akan menjadi mandiri dan terwujudkan kampung kreatif.

\section{KONSEP}

Konsepnya seperti perusahaan. UKM sektor kerajinan membenahi terlebih dahulu manajemen pengeloaannya. Masyarakat sekitar UKM dipersilahkan untuk terlibat dalam proses pembuatan produk, pemasaran, pengeloaan keuangan (internship). Masyarakat yang dinyatakan berhasil (lulus), melalui beberapan tahapan ujian akan dibantu dalam mewujudkan usaha baru. Pemakaian mesin dapat dilakukan secara sharing, bantuan bahan baku serta pemasaran. UKM utama dapat membeli produk yang dihasilkan masyarakat maupun membuka distribusi pasar yang baru.

\section{MODEL BISNIS}

UKM akan mensuplay bahan baku serta peralatan yang akan digunakan untuk membuat produk. Produk yang dihasilkan masyarakat akan dibeli UKM dengan harga yang kompetitif. UKM akan menjual kepada pihak lain maupun memasarkan sampai keluar daerah. Uang yang diterima UKM akan diberikan kepada masyarakat sekitar dengan terlebih dahulu dipotong biaya bahan baku maupun sewa peralatan. Keuntungan yang diperoleh UKM akan digunakan kembali untuk memberikan pelatihan kepada masyarakat. Kegiatan sosialiasi dan edukasi pada masyarakat akan berkolaborasi dengan pemerintah daerah dan CSR perusahaan.

Dari contoh diatas, implementasi kewirausahaan sosial berbasis ekonomi kreatif dapat dimulai dari kondisi yang terjadi didaerah masing-masing. Ide yang muncul disesuaikan dengan harapan yang diinginkan dari kegiatan yang akan dilakukan.

Permasalahan sosial dapat diatasi dengan solusi bisnis agar dapat lebih mandiri dan berkelanjutan. Tidak tepat jika mengibaratkan misi sosial dan kegiatan bisnis seperti air dan minyak, akan lebih tepat jika diibaratkan seperti garam dan gula. Apabila dikombinasikan dengan kadar yang tepat, dapat membuat masakan menjadi lezat dan memberi rasa nyaman dan enak bagi siapa pun yang memakannya.

\section{F. Simpulan dan Saran}

1. Simpulan

Dari hasil uraian diatas dapat disimpulkan sebagai berikut : 
a) Implementasi dan pengembangan social entrepreneurship berbasis ekonomi kreatif masih memiliki beberapa kelemahan diantaranya : masih banyak pengrajin yang berjalan sendiri-sendiri dalam mengelola usahanya dan koordinasi dengan pemerintah daerah masih belum optimal. Komunitas pengrajin belum berjalan optimal dalam meningkatkan kualitas usaha pengrajin sehingga terkesan mereka (pengrajin) saling bersaing sesama pengrajin sendiri.

b) Ide kreatif dan terobosan inovasi untuk mengembangkan produk sudah cukup baik, tetapi tetap perlu didukung oleh pemerintah. Pemerintah harus dilibatkan untuk mendukung usaha mereka khususnya dalam mengeluarkan aturan yang berpihak pada pengrajin.

c) Minimnya generasi muda untuk meneruskan usaha kerajinan oleh keluarga menjadikan jumlah pengrajin berkurang. Selain itu, tingkat pendidikan yang relatif rendah dan usia yang tidak lagi produktif dapat menjadi kendala dalam implementasi social entrepreneurship.

d) Konsep kewirausahaan sosial yang akan dijalankan harus berorientasi pada permasalahan sosial yang dihadapi masyarakat, dengan mengedepankan pemberdayaan dan kerjasama dengan berbagai pihak.

e) Kegiatan usaha sosial yang dilakukan harus berdampak pada perubahan pada masyarakat untuk jangka panjangnya.

\section{Saran}

Saran yang dapat dilaksanakan sesuai dari hasil penelitian sebagai berikut :

a) Pemerintah daerah berserta komunitas pengrajin harus peka terhadap permasalahan sosial yang dihadapi masyarakat dilingkungannya, dengan ikut melakukan perubahan melalui kegiatan usaha yang dapat memunculkan kemandirian.

b) Pendampingan, kontrol dam evaluasi dapat dilakukan secara bersama-sama terhadap usaha untuk mewujudkan kegiatan sosial.

c) Komunitas pengrajin kerajianan harus mampu menjadi pelopor untuk menjadi agen perubahan dengan ikut membantu pemerintah daerah menanggulangi kesenjangan sosial melalui usaha sosial

\section{G. Referensi}

A, H. (2008). Langkah Mudah Mengembangkan dan Memanfaatkan Weblog. Yogyakarta: Andi.

A, N. (2006). Social Entrepreneurship New Model of Sustainable Change. Oxford: Oxford University Press.

Adimiharja K, H.H. (2003). Participatory Research Appraisal: Pengabdian Pemberdayaan Masyarakat. Bandung: Humaniora.

Alexander Osterwalder, Yves Pigneur. (2009). Business Model Generations. New York: Wiley.

Astridya Paramita dan Lusi Kristiana. (2013, April 2). Tenik Focus Group Discussion dalam Penelitian Kualitatif. Buletin Penelitian Sistem Kesehatan volume 15, p. 30.

Bornstein, D. (2007). How to Change the World. New York: Oxford University Press.

Braun, K. (2009, April 2). Social Entrepreneurship: Perspective on Academic Discipline. Theory in Action Volume 2, p. 20.

Darmano. (2017, Mei 27). Logic Emotion. Retrieved from darmano.typepad.com: http://darmano.typepad.com/logic_emotion/ 
Diman. (2017, Mei 27). upload. Retrieved from bsn.go.id: http://www.bsn.go.id/uploads/download/Kesiapan_Tasikmalaya_menghadapi_MEA_BudiBu diman1.pdf

dkk, A. G. (2002). The Process of Social Entrepreneurship: Creating Opportunities Worthy of Serious Pursuit. Duke The Fuqua School of Bussiness .

E, M. J. (2005). How intentions to create a social venture are formed - A case study. IESE Business School. (Vol. 593), 593.

Firdaus, N. (2014). Pengentasaan Kemiskinan Melalui Pendekatan Kewirausahaan Sosial . Jurnal Ekonomi dan Pembangunan Vol 22, 1-10.

Fram EH, MS McCarthy. (2009). Retaining Customer Satisfaction in Turbulent Times. International Journal of Bank Marketing, 555-562.

H, U. (2014). Menumbuhkan Minat Kewirausahaan Sosial. Bandung: Among Makarti.

Haryadi E, SJ Waluyo. (2006). Kewirausahaan Sosial LSM Bina Swadaya: Refleksi Pernajalan dalam Menjalankan Misi Pemberdayaan Masyarakat. Jurnal Galang, 109-124.

Hurgald, L. (2010). Discourses of Social Entrepreneurshi-Variation of the Same Theme? EMES European Research Network.

I, M. J. (2006). Social entrepreneurship : A souce of explanation, prediction and delight. Journal of World Business, $36: 44$.

Ilmu Ekonomi. (2017, Mei 2017). Retrieved from dosenekonomi.com: http://dosenekonomi.com/ilmuekonomi/tujuan-ekonomi-kreatif/

Jiao, H. (2011). A Conceptual Model for Social Entrepreneurship Directed Toward Impact on Society. Social Enterprise Journal volume 7, 130-149.

Madcoms. (2010). Facebook, Twitter dan Plurk dalam Satu Genggaman. Yogyakarta: Andi.

Manuel London, Richard G. Morfopoulos. (2010). Social Entrepreneurship: How to Start Successful Corporate Social Responsibility and Community-based Initiatives for Advocacy and Change. Wiley: New York.

Noruzi MR, JH Westover, GR Rahimi. (2014). An Exploration to Social Entrepreneurship in the Entrepreneurship Era. Asian Social Science, 3-10.

Palesangi, M. (2012). Pemuda Indonesia dan Kewirausahaan Sosial. Bandung: Universitas Katolik Parahyangan.

Patra SK, SC Nath. (2014). Social Transformation trough Social Enterpreneurship: An Explanatory Study. The IUP Journal of Enterpreneurship Development volume XI, 7-17.

Perrini F, C Vurro. (2006). Social Entrepreneurship: Innovation and Social Change Across Theory and Practice. In J. R. J Mair, Social Entrepreneurship (pp. 57-85). New York: Palgrave Macmillan.

Rahmawati, P. (2011). Pengembangan Metode Pembelajaran Pendidikan Kewirausahaan Sosial. Jurnal Pendidikan Inovatif, 1-15.

Situmorang DBM, IR Miranti. (2012). Socail Entrepreneurship to Develop Ecotourism. Procedia Economic and Finance, 298-405.

Sofia, I. P. (2015). Konstruksi Model Kewirausahaan Sosial sebagai Gagasan Inovasi Sosial bagi Pembangunan Perekonomian. Jakarta: Universitas Pembangunan Jaya.

Steinerowski A, J. S. (2008). Who are the social entrepreneurs and what do they actually do?. . Frontiers of Entrepreneurship Research $28,21$.

Stephen P Robbins, Mary Coulter. (2012). Management. New Jersey: Pearson.

Yunus, M. (2007). Creating a World Without Poverty: Social Business and the Future of Capitalism. New York: Perseus Book.

Zarrella, D. (2010). The Social Media Marketing Book. Jakarta: PT. Serambi Ilmu Semesta. 
